\title{
A NIR probe tracks and treats lung tumor initiating cells by targeting HMOX2
}

Jong-Jin Kim ${ }^{a, b}$,, Yong-An Lee ${ }^{a, e}$, , Dongdong Su ${ }^{a}$, Jungyeol Lee ${ }^{c, d}$, Sung-Jin Park ${ }^{a}$, Beomsue Kim ${ }^{a}$, Jia

Hui Jane Lee e, ${ }^{\text {, }}$ Xiao Liu ${ }^{b, d}$, Seong Soon Kim ${ }^{\circ}$, Myung Ae Bae ${ }^{\circ}$, Jun-Seok Lee ${ }^{g}$, Seong Cheol Hong ${ }^{g}$, Lu

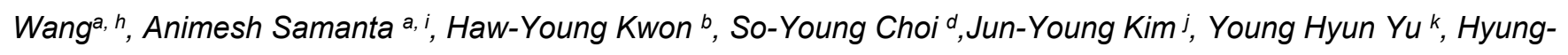

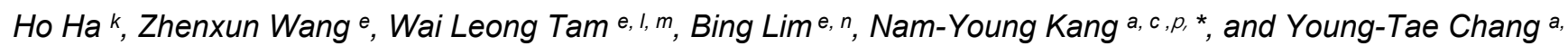
$b, d, *$

a Laboratory of Bioimaging Probe Development, Singapore Bioimaging Consortium, Agency for Science, Technology and Research (A*STAR), Singapore 138667, Singapore, ${ }^{b}$ Center for Self-assembly and Complexity, Institute for Basic Science (IBS), Pohang 37673, Republic of Korea, ${ }^{\mathrm{c}}$ New drug discovery center, DGMIF, Daegu 41061, Republic of Korea, d Department of Chemistry, Pohang University of Science and Technology (POSTECH), Pohang 37673, Republic of Korea, e Genome Institute of Singapore, Agency for Science,

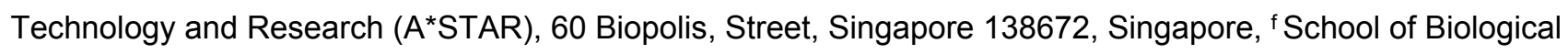
Sciences, Nanyang Technological University, Singapore 637551, Singapore, 9 Molecular Recognition Research Center, Korea Institute of Science and Technology, 5, Hwarang-ro 14-gil, Seoul 02792, Republic of Korea, ${ }^{h}$ Department of Chemical Biology, Max Planck Institute for Medical Research, Heidelberg 69120, Germany, ${ }^{i}$ Chemical Sciences and Technology Division, CSIR - National Institute for Interdisciplinary Sciences and Technology (CSIR - NIIST), Industrial Estate P O, Pappanamcode, Thiruvananthapuram 695019, India, ${ }^{j} A-4{ }^{\text {th }}$, SL VAXiGEN, KOREA BIO PARK, Daewangpangyo-ro 700, Bundang-gu, Seongnam-si, Gyenggi-do, Korea, ${ }^{k}$

Department of Pharmacy, and Research Institute of Life Pharmaceutical Sciences 11 Sunchon National University, Suncheon 57922, Republic of Korea, ' Cancer Science Institute of Singapore, National University of Singapore, Singapore 117599, Singapore, m Department of Biochemistry, Yong Loo Lin School of Medicine, National University of Singapore, Singapore 117597, Singapore, ${ }^{n}$ Merck Sharp and Dohme Translational Medicine Research Centre, 8A Biomedical Grove, Singapore 138648, Singapore, ${ }^{\circ}$ Bio \& Drug Discovery Division, Korea Research Institute of Chemical Technology, Yuseong-Gu, Gajeong-ro 141, Daejeon 34114 , Republic of Korea. ${ }^{\mathrm{p}}$ Department of Creative IT Engineering, Pohang University of Science and Technology (POSTECH), Pohang, Gyeongbuk 37673, Korea 


\section{Compound Information}

3 - General information

$4 \quad$ - Synthesis of TiNIR

5

6 2. Supporting Figure

$7 \quad$ - Figure S1. Selection of hit compound.

8 - Figure S2. Validation of TiNIR selectivity for TICs on the patient-derived lung cancer (A139) cells.

9 - Figure S3. Behavior of TiNIR in vivo.

10 - Figure S4. Scheme of target identification.

11 - Figure S5. Therapeutic effect of TiNIR on the lung cancer.

12 - Figure S6. Assessment of the universality of TiNIR for TIC identification.

\section{Supporting Table}

- Table S1. The list of identified proteins from gel bands in the gel pieces by LCMS analysis. 


\section{Compound Synthesis and Characterization}

General information: All the chemicals and solvents were purchased from Sigma Aldrich, Alfa Aesar, $\mathrm{TCl}$, and used without further purification. Normal phase purifications were carried out using Merck Silica Gel 9385 (pore size $60 \AA$, particle size: 0.040-0.063 mm, 230-400 mesh). Synthetic reactions and analytical characterization were monitored by HPLC-MS (Shimadzu, LCMS-2010) with a single quadrupole mass spectrometer. Mobile phase $\mathrm{A}: \mathrm{H}_{2} \mathrm{O}(0.1 \% \mathrm{HCOOH})$, mobile phase $\mathrm{B}: \mathrm{CH}_{3} \mathrm{CN}(0.1 \%$ $\mathrm{HCOOH}$ ), gradient: 0-0.5 min $5 \% \mathrm{~B}, 0.5-13$ min gradient from $5 \% \mathrm{~B}$ to $95 \% \mathrm{~B}, 13-15 \mathrm{~min}, 95 \% \mathrm{~B}$. Column: C18 (2) Luna column ( $250 \times 4.6 \mathrm{~mm}, 5 \mu \mathrm{m}$ particle size). NMR spectra $\left({ }^{1} \mathrm{H} 400 \mathrm{MHz}\right.$ and ${ }^{13} \mathrm{C}$ $101 \mathrm{MHz}$ ) were recorded on Bruker Avance 400 NMR spectrometers. Spectroscopic and quantum yield data were measured on spectroscopic measurements, performed on a fluorometer and UV/VIS instrument, Spectra Max M2 by Molecular Device. The slit width was $5 \mathrm{~nm}$ for both excitation and emission, and the data analysis was performed using GraphPrism 5.0. The relative quantum yield was calculated by comparing the areas under the corrected emission spectrum. The following equation was used to calculate quantum yield.

where $\Phi_{\text {st }}$ is the reported quantum yield of the standard, $I$ is the integrated emission spectrum, $A$ is the absorbance at the excitation wavelength, and $\eta$ is the refractive index of the solvents used. The subscript " $x$ " denotes unknown and "st" denotes standard. Rhodamine B was used as a standard.

36

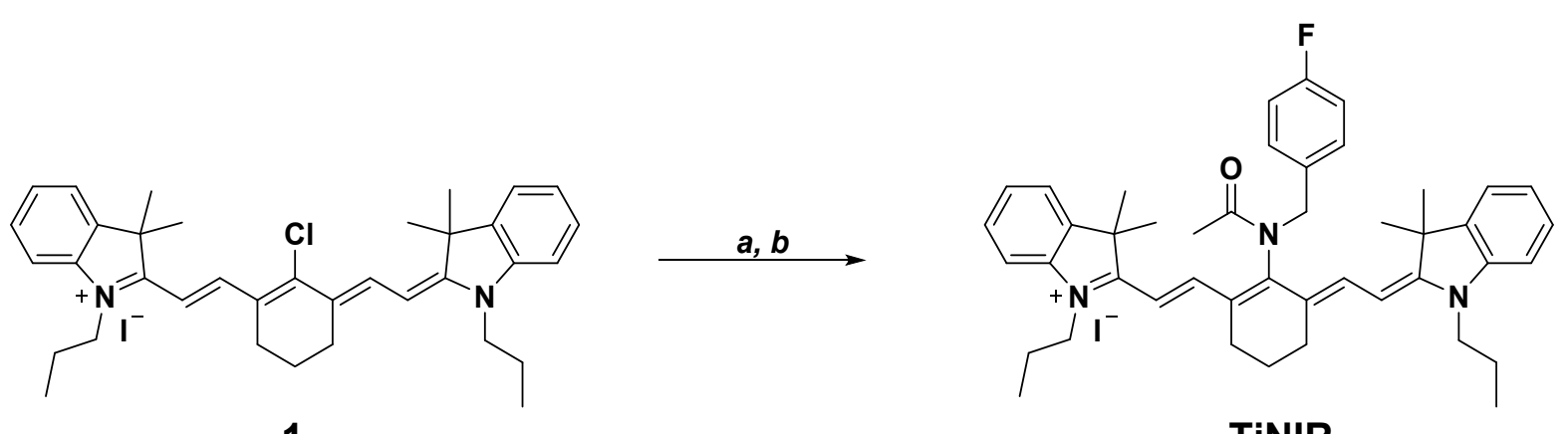

$$
\Phi_{\mathrm{x}}=\Phi_{\mathrm{st}}\left(I_{x} / I_{s t}\right)\left(A_{s t} / A_{x}\right)\left(\eta_{x}^{2} / \eta_{s t}^{2}\right)
$$

Synthetic scheme of TiNIR. Reagent and conditions: (a) 4-fluorobenzylamine, DIPEA, MeCN, $80{ }^{\circ} \mathrm{C}$, 80 min; (b) acetyl chloride, DIEA, $\mathrm{CH}_{2} \mathrm{Cl}_{2}, 0^{\circ} \mathrm{C}, 5 \mathrm{~min}$. (11\% in 2 steps)

\section{Experimental Procedure}

Synthesis of TiNIR : Compound 1 was prepared according to the known procedure ${ }^{1}$. To a solution of compound 1 (250 mg, $0.375 \mathrm{mmol}$ ) in anhydrous acetonitrile $(20 \mathrm{~mL}$ ) was added 4-fluorobenzylamine (93.8 $\mathrm{mg}, 0.750 \mathrm{mmol})$ and DIPEA $(98 \mu \mathrm{L}, 0.563 \mathrm{mmol})$. The reaction mixture was heated for $80 \mathrm{~min}$ at $80{ }^{\circ} \mathrm{C}$. The resulting blue color reaction mixture was neutralized with $0.1 \mathrm{~N} \mathrm{HCl}$, and concentrated under vacuum. Resulting crude was dissolved in anhydrous dichloromethane $(20 \mathrm{~mL})$ under $\mathrm{N}_{2}$ atmosphere, and then treated with excess DIEA $(650 \mu \mathrm{L}, 3.75 \mathrm{mmol})$ and acetyl chloride $(40 \mu \mathrm{L}, 0.562 \mathrm{mmol})$ at 0 ${ }^{\circ} \mathrm{C}$ for $5 \mathrm{~min}$. The reaction mixture was washed with $0.1 \mathrm{~N} \mathrm{HCl}$, concentrated under vacuum. The residue 
was purified by flash column chromatography to afford compound $33 \mathrm{mg}$ of TiNIR. (11\% in 2 steps) ${ }^{1} \mathrm{H}$ NMR (400 MHz, $\left.\mathrm{CDCl}_{3}\right) \delta 7.96$ (d, $\left.J=13.6 \mathrm{~Hz}, 2 \mathrm{H}\right), 7.43$ (dd, $\left.J=8.5,5.6 \mathrm{~Hz}, 2 \mathrm{H}\right), 7.31(\mathrm{~d}, J=7.4 \mathrm{~Hz}$, $2 \mathrm{H}), 7.18(\mathrm{t}, J=7.4 \mathrm{~Hz}, 2 \mathrm{H}), 7.01(\mathrm{~d}, J=7.8 \mathrm{~Hz}, 2 \mathrm{H}), 6.88(\mathrm{t}, J=8.7 \mathrm{~Hz}, 2 \mathrm{H}), 6.03(\mathrm{~d}, J=13.6 \mathrm{~Hz}, 2 \mathrm{H})$, $4.39(\mathrm{~d}, J=5.7 \mathrm{~Hz}, 2 \mathrm{H}), 4.09(\mathrm{~s}, 2 \mathrm{H}), 3.93(\mathrm{t}, J=7.3 \mathrm{~Hz}, 4 \mathrm{H}), 2.61-2.54(\mathrm{~m}, 4 \mathrm{H}), 1.91-1.80(\mathrm{~m}, 6 \mathrm{H})$, $1.58(\mathrm{~s}, 12 \mathrm{H}), 1.03(\mathrm{t}, J=7.4 \mathrm{~Hz}, 6 \mathrm{H})$.

${ }^{13} \mathrm{C} \mathrm{NMR}\left(101 \mathrm{MHz}, \mathrm{CDCl}_{3}\right) \delta 171.73,169.41,163.06,160.64,154.60,143.67,142.39,141.41,135.46$, $135.43,132.17,130.64,130.56,128.45,124.88,122.51,114.99,114.78,110.09,100.49,49.21,45.75$, 42.72, 36.84, 29.79, 28.37, 25.68, 20.76, 11.80 .

\section{ESI-MS $m / z\left(\mathrm{C}_{45} \mathrm{H}_{53} \mathrm{FN}_{3} \mathrm{O}^{+}\right)$, calculated: 670.42 , found: $670.40\left[\mathrm{M}^{+}\right]$.}

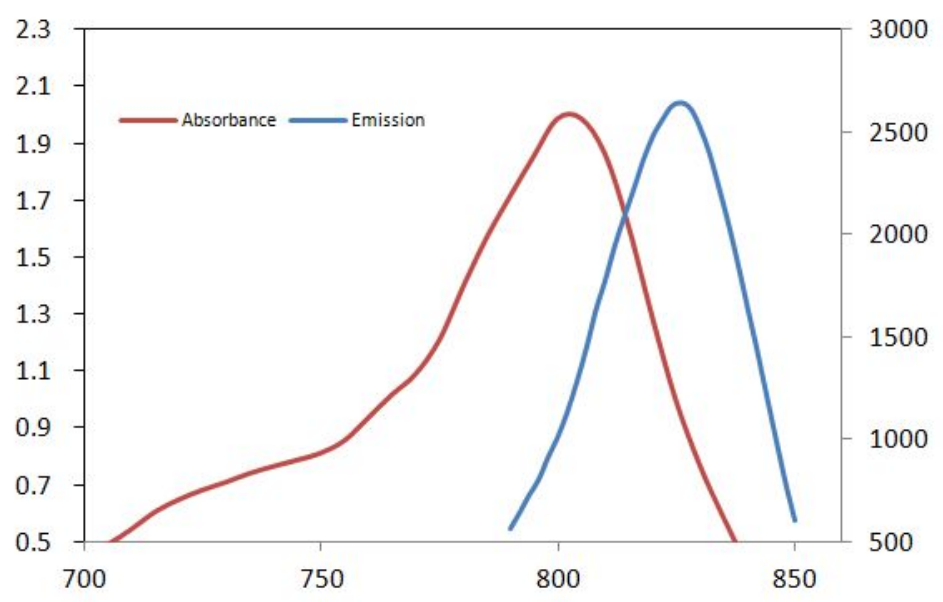

Fluorescence absorbance and emission spectrum of TiNIR. $\lambda_{\max }$ of exciation $=805 \mathrm{~nm}, \lambda_{\max }$ of emission $=825 \mathrm{~nm}(10 \mu \mathrm{M}$ in DMSO $)$

Quantum Yield $(\Phi)$ : 0.09 (Solvent: DMSO, Reference Dye: Rhodamine B, Excitation wavelength $\left(\lambda_{\mathrm{ex}}\right)$ : 750 nm) 


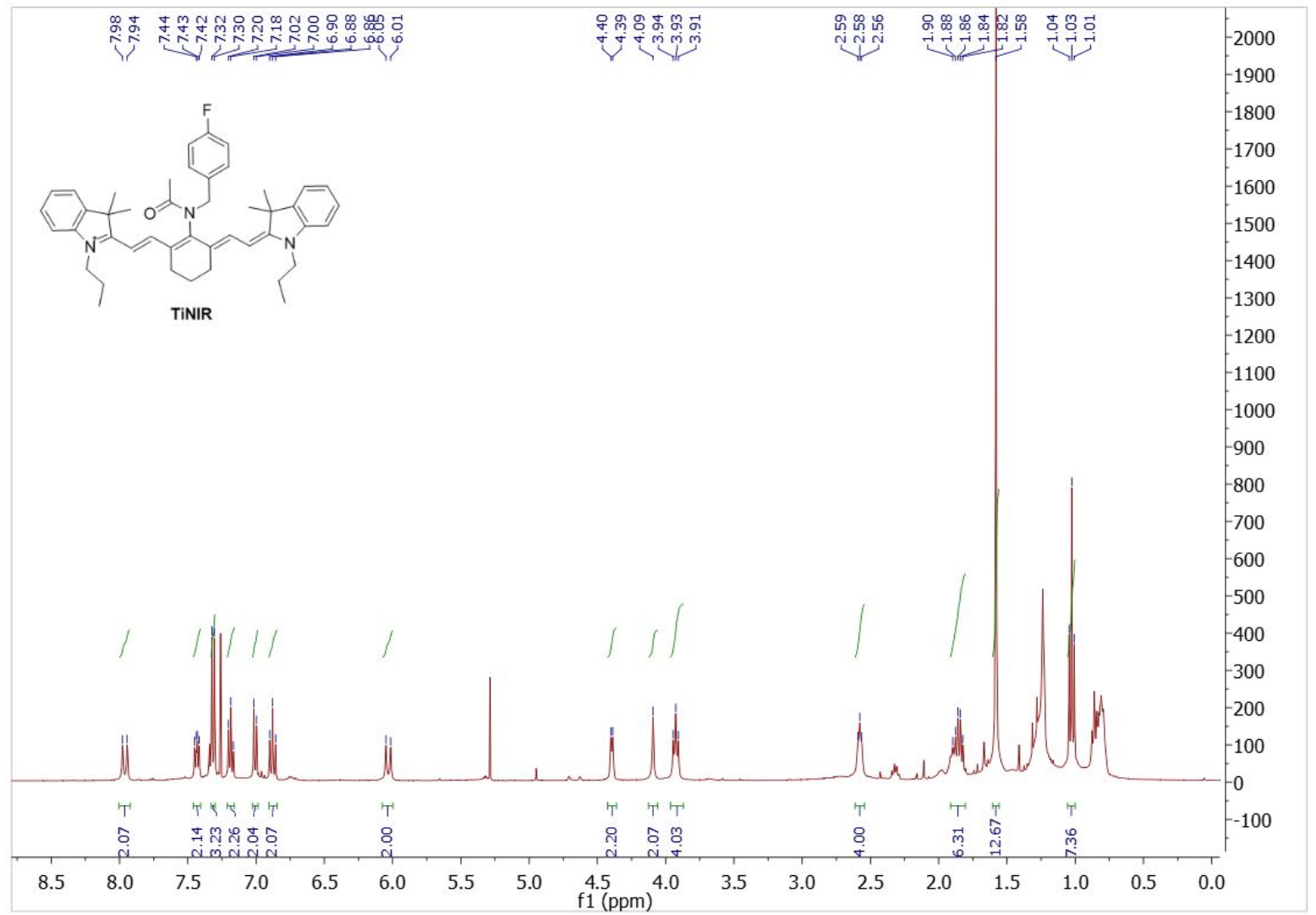

${ }^{1} \mathrm{H}$ NMR $\left(400 \mathrm{MHz}, \mathrm{CDCl}_{3}\right)$ spectrum of compound TiNIR. 


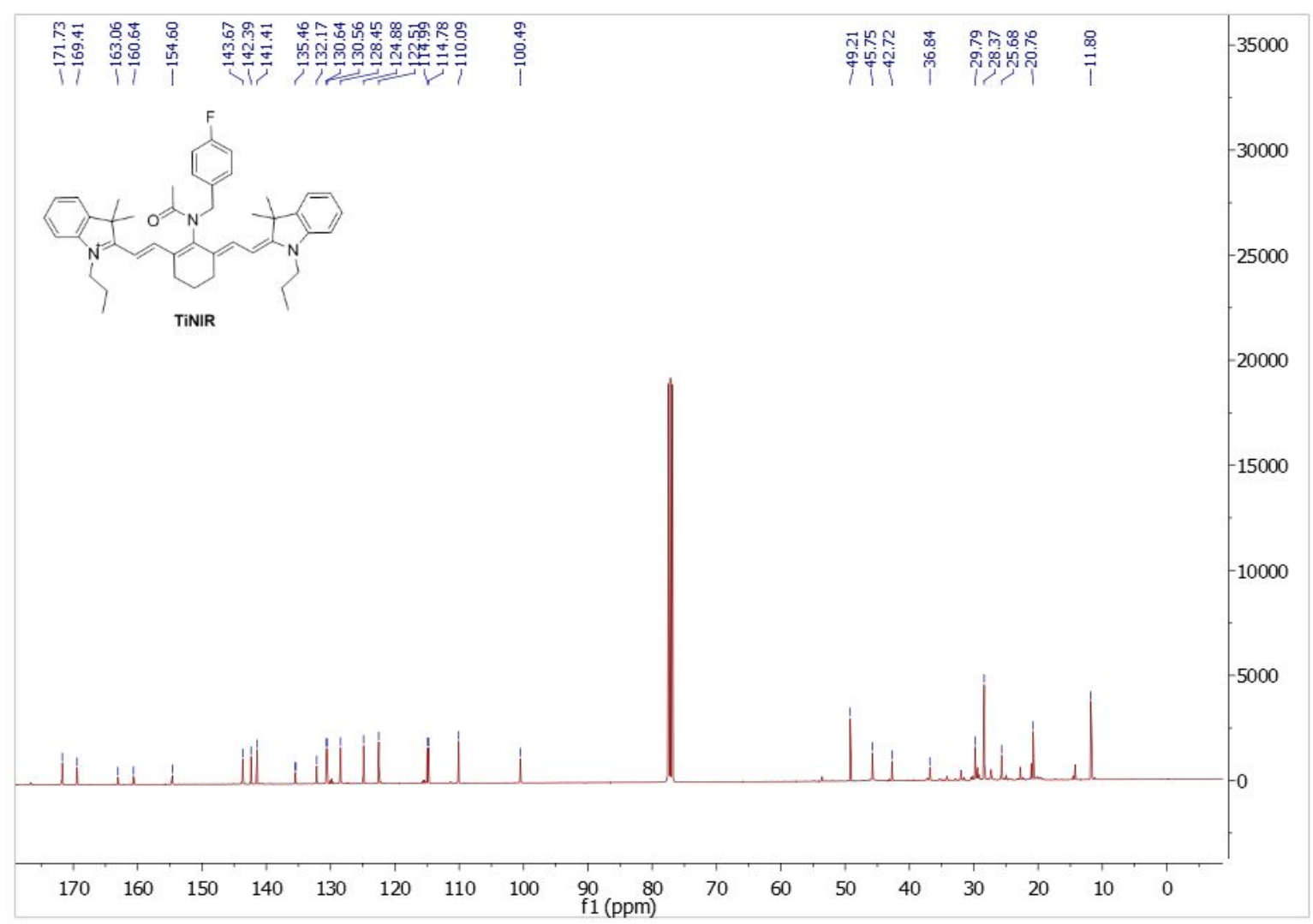
${ }^{13} \mathrm{C}$ NMR (100 MHz, $\mathrm{CDCl}_{3}$ ) spectrum of compound TiNIR. 


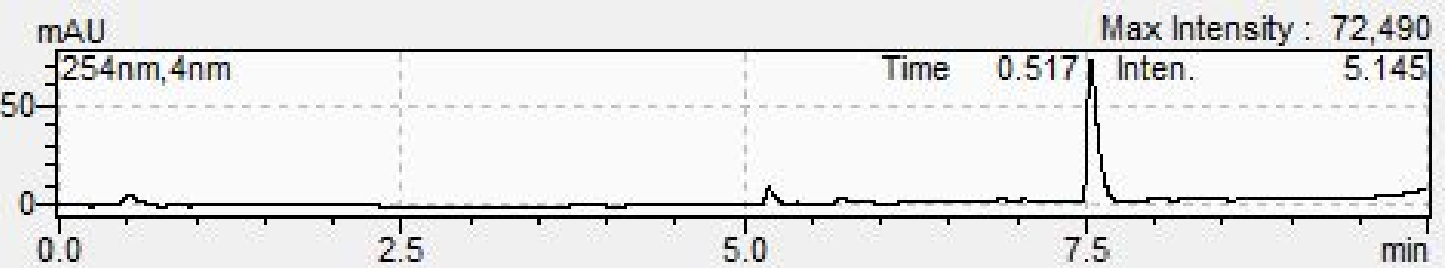

mAU

Max Intensity: 6,578

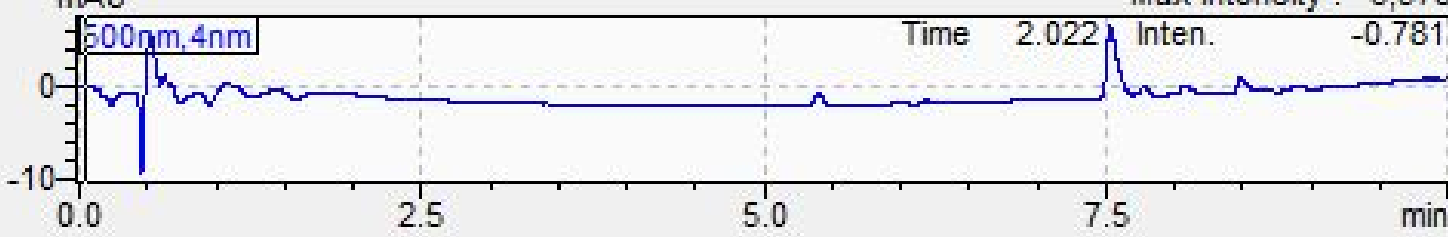

mAU

Max Intensity : 69,363

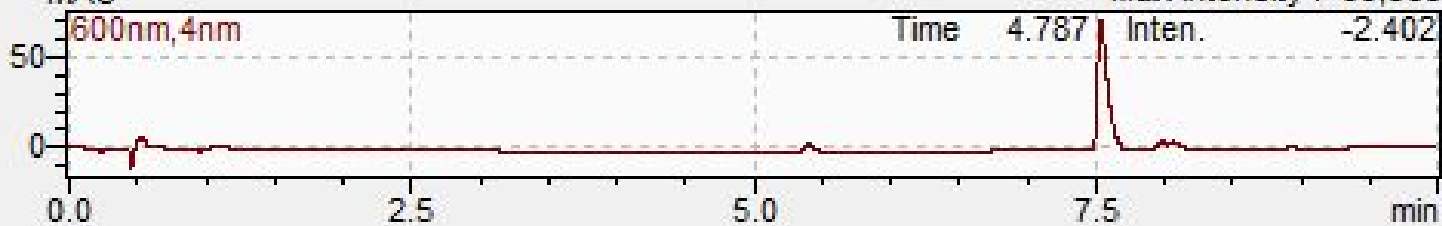

MAU

Max Intensity : 1,403,671

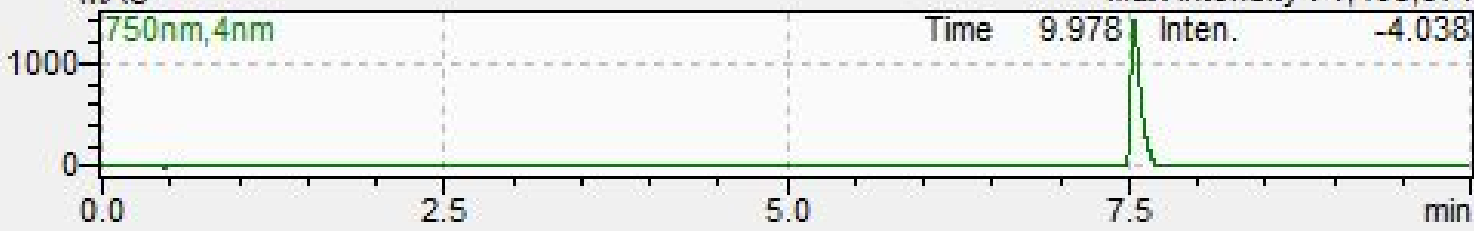

HPLC spectrum of compound TiNIR.

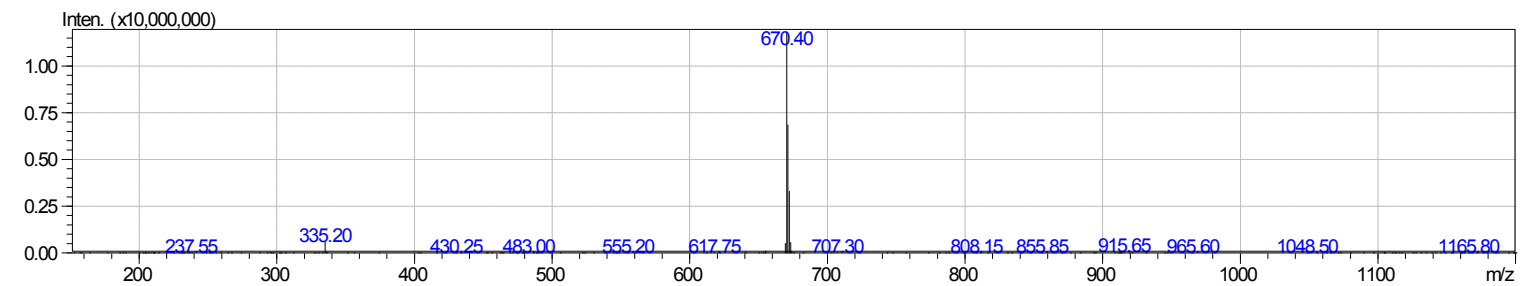


A

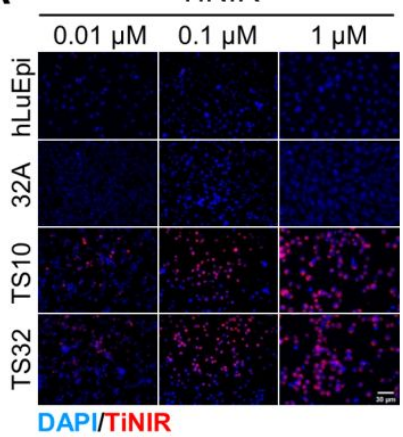

C

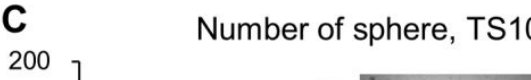

B
80
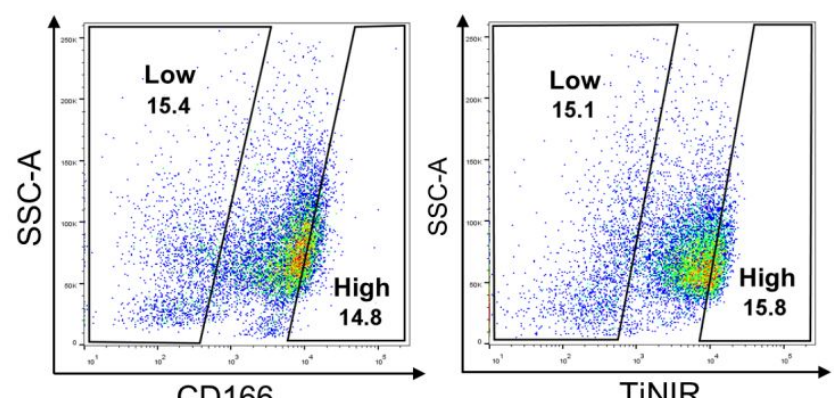

D

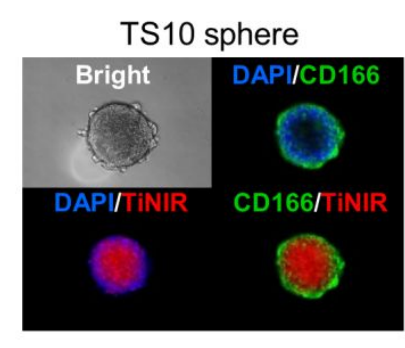

TS32 sphere

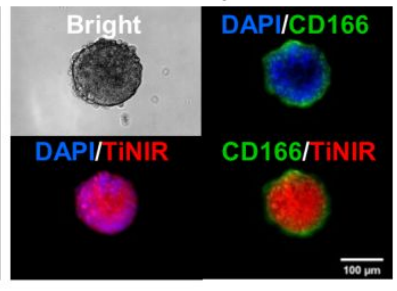

Figure S1. Selection of hit compound. (A) Fluorescence images (magnification $\times 20$ ) of four kinds of cells after treatment with TiNIR. Various concentrations $(0.01,0.1$, and $1 \mu \mathrm{M})$ of TiNIR and DAPI (1 $\mu \mathrm{g} / \mathrm{mL}$ ) treated $32 \mathrm{~A}, \mathrm{hLuEpi}, \mathrm{TS} 10$, and TS32 cells for $40 \mathrm{~min}$. Fluorescence images were confirmed by microscopy (magnification $\times 20$ ). (B) Comparison of staining pattern between anti-CD166 antibody $(1 \mu \mathrm{g} / \mathrm{mL})$ and TiNIR $(10 \mathrm{nM})$ and sorting strategy of TS10 cell line. After analysis, each population (total, CD166low, CD166 high, TiNIRlow, and TiNIR high) were sorted (4000 cells/group) for evaluating the ability of sphere forming. Sorting percentages are indicated for each region. (C) Spheres were counted at day 6. Microscopy images showed the representative spheres (magnification $\times 4$ ). $N=3$. (D) Confirmation of permeability of TiNIR on the sphere staining. Spheres (TS10 and TS32) are treated with TiNIR (100 nM), anti-CD166 antibody $(1 \mu \mathrm{g} / \mathrm{mL})$ and DAPI $(1 \mu \mathrm{g} / \mathrm{mL})$ for 6 hours. 
A
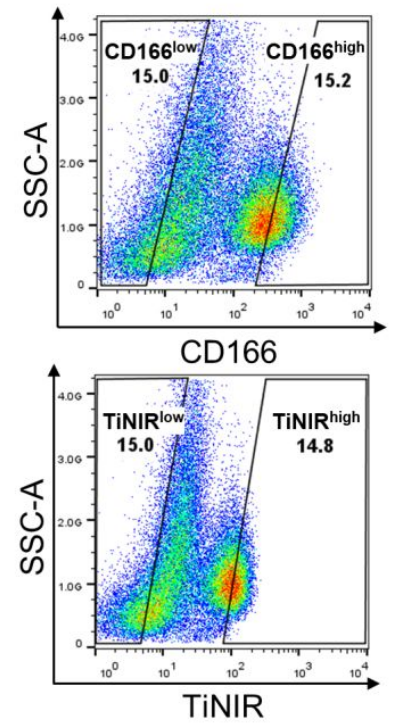

C

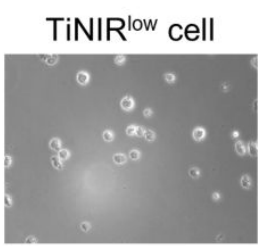

TiNIR ${ }^{\text {high }}$ cell

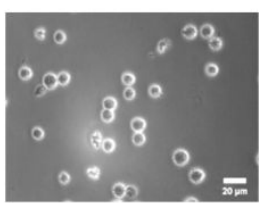

B

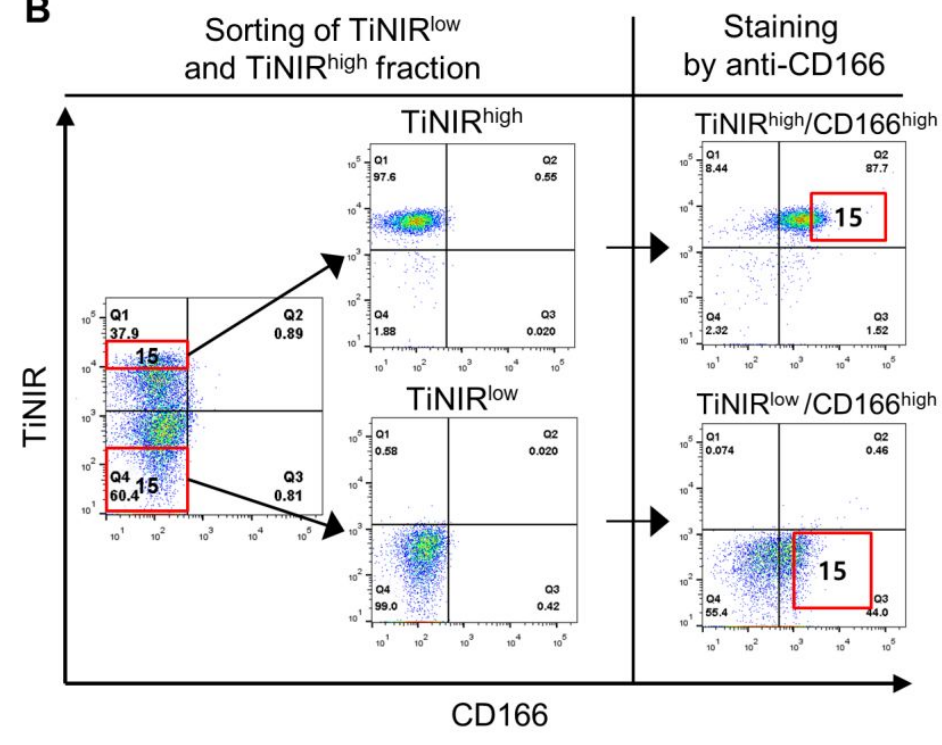

E

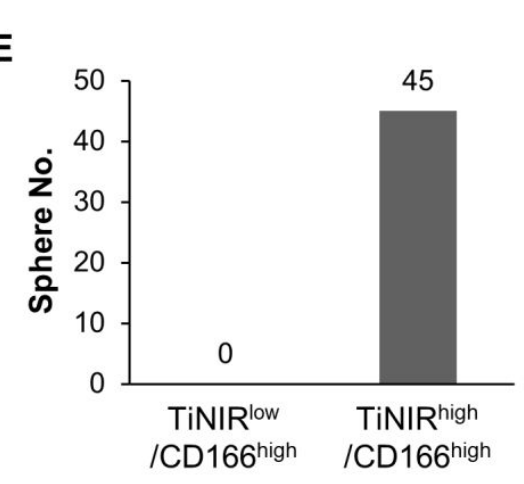

\section{D}
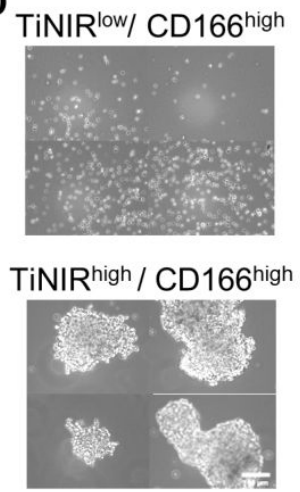

Figure S2. Validation of TiNIR selectivity for TICs on the patient-derived lung cancer (A139) cells. (A) Sorting strategy for low and high intensity population of A139 PDX cells after staining with anti-CD166 $(1 \mu \mathrm{g} / \mathrm{mL})$ or TiNIR (10 $\mathrm{nM})$. (B) Sorting strategy of CD166 high fraction from TiNIRlow or TiNIR high fraction in the A139 PDX cells. First, TiNIR low or TiNIR high fractions were sorted after staining with TiNIR (10 nM) (left). After sorting, purity of each fraction was confirmed (middle) and stained by the anti-CD166 antibody. $15 \%$ of each TiNIRlow/CD166 high and TiNIR ${ }^{\text {high }} /$ CD166 high fractions were sorted (right). (C) Cell images of each fraction (magnification $\times 20$ ). (D-E) Sphere forming abilities of TiNIRlow/CD166 high and TiNIR high/CD166 high fraction. After culture for 6 days, spheres were counted under microscopy (magnification $\times 10)$. 


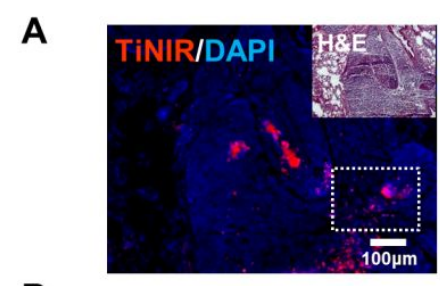

B

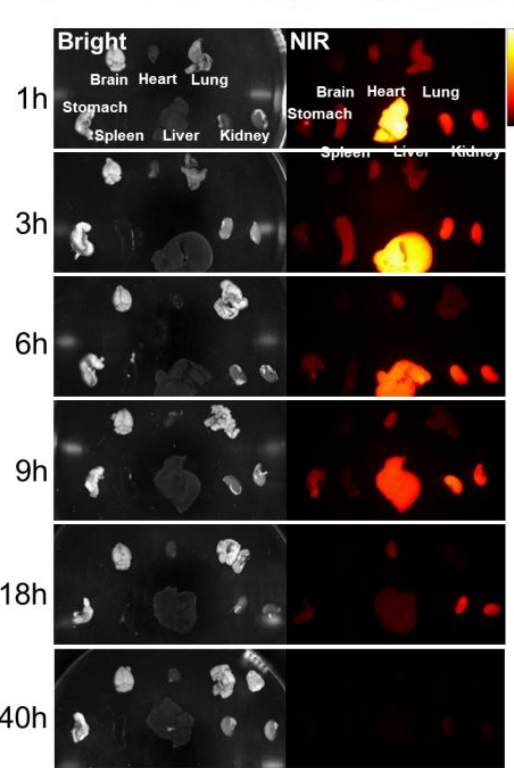

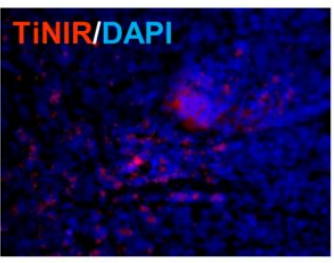

C
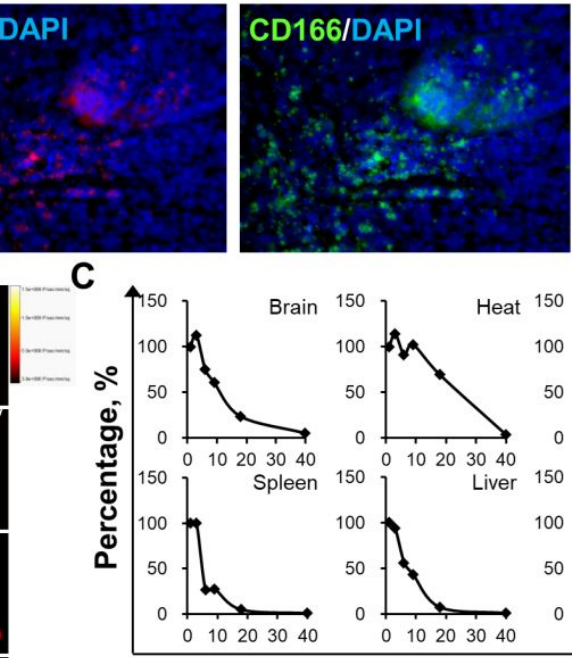
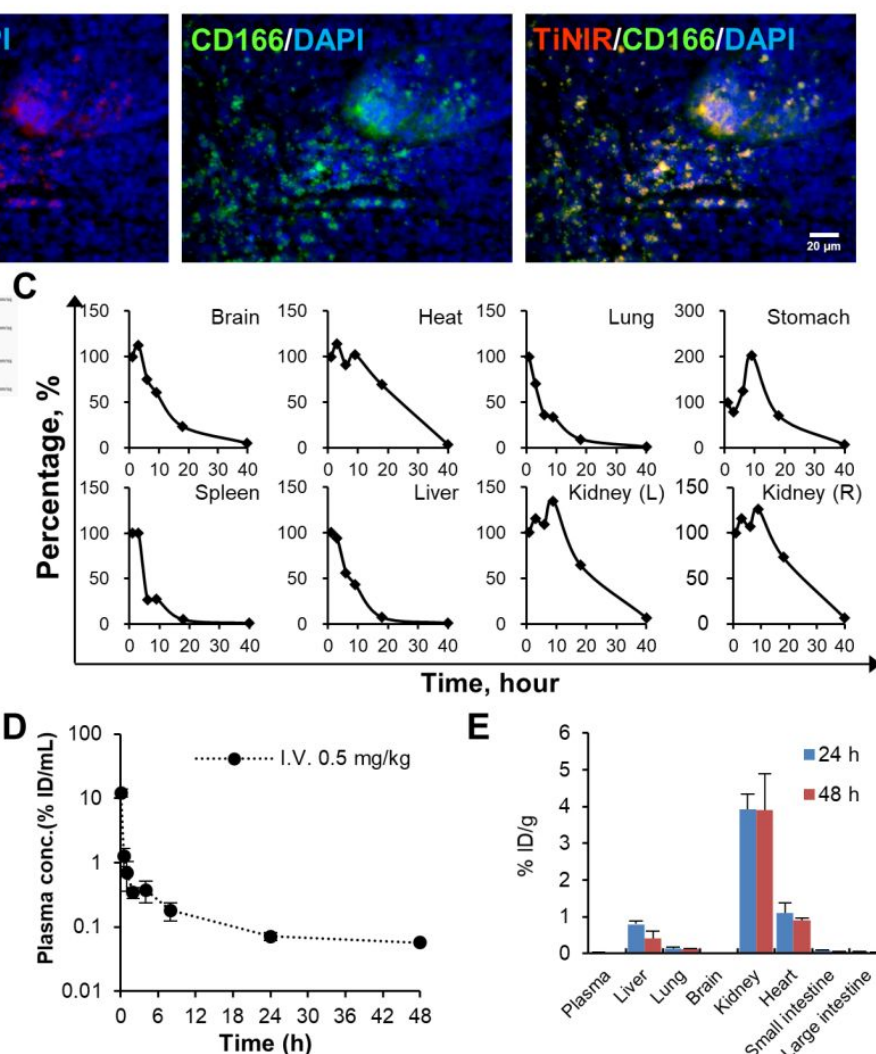

E

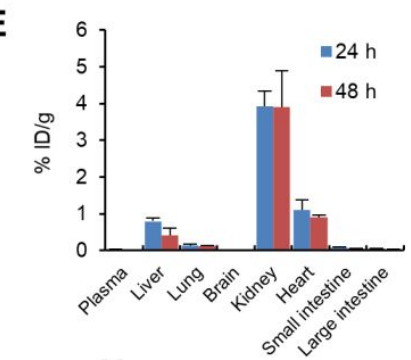

H

F G
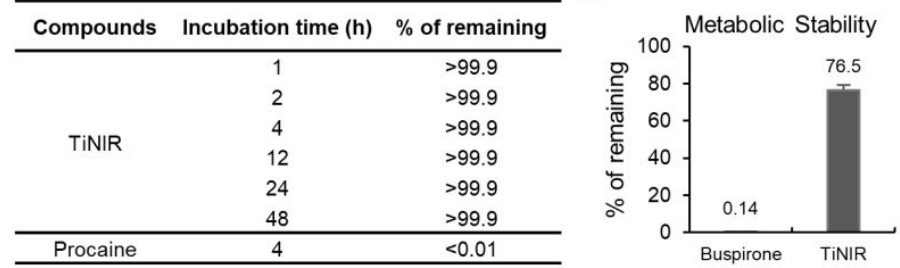

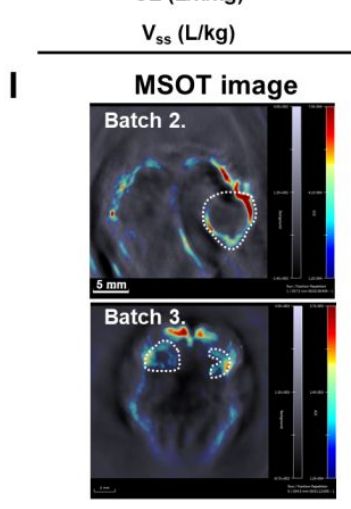

K

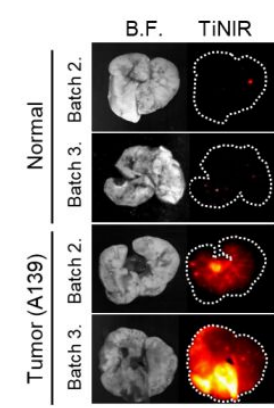
$6.84 \pm 2.03$

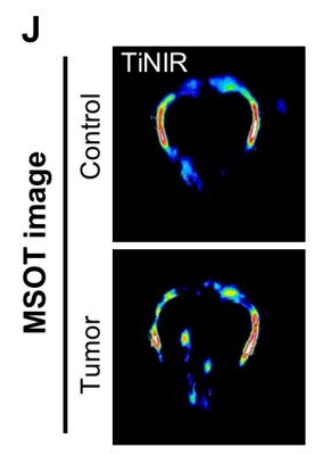

L

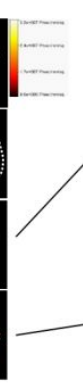

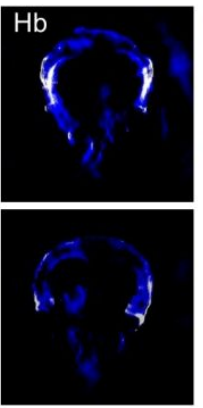
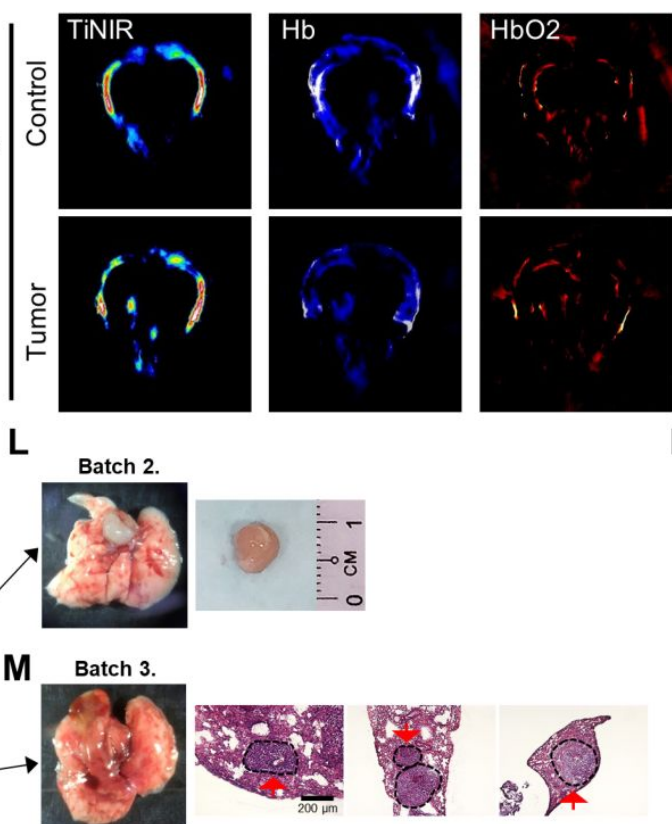

N
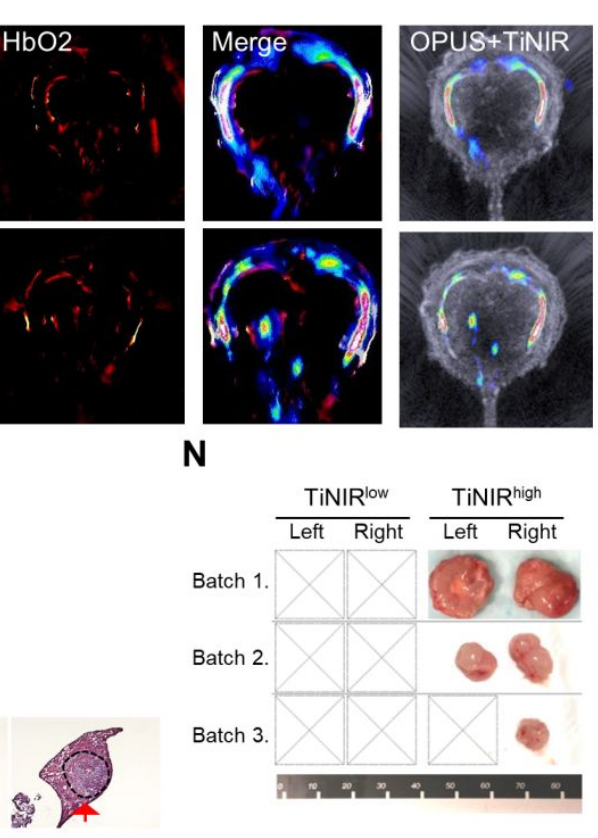
104 Figure S3. Behavior of TiNIR in vivo. (A) Histological analysis of TS32-derived mouse lung tumor using

105 TiNIR and CD166 antibody. Tumor-induced lung was stained by H\&E or TiNIR (100 $\mu$ M) /anti-CD166

$106(1 \mu \mathrm{g} / \mathrm{mL}) /$ DAPI $(1 \mu \mathrm{g} / \mathrm{mL})$ for analysis of tumor and TICs area. (B-C) Biodistribution of TiNIR in the 107 organs of a normal mouse. TiNIR $(100 \mu \mathrm{M}, 100 \mu \mathrm{L} / 10 \mathrm{~g})$ was injected into a normal mouse and 108 sacrificed at the indicated time. Signal changes of TiNIR in the organs were checked and analyzed by 109 In-vivo Xtreme (Bruker). (D-H) Pharmacokinetic analysis of TiNIR after tail vein injection. (D) Plasma 110 concentration of TiNIR in the mice. \%ID/g is calculated as follows: $100 \times$ [plasma concentration $(\mu \mathrm{g} / \mathrm{g})$ ]

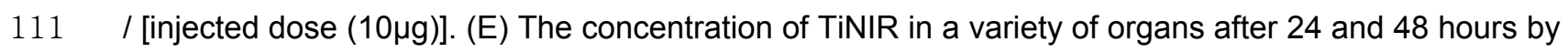
112 injection of TiNIR. (F) Pharmacokinetic parameters after tail vein injection in mice. (G) In vitro stability 113 of TiNIR in mouse plasma. Procaine was used as a positive control. \% of remaining after various 114 incubation time at $37^{\circ} \mathrm{C}$. $(\mathrm{H})$ In vitro metabolic stability of TiNIR in the liver microsomes of mouse. \% of 115 remaining after 1 hour at $37^{\circ} \mathrm{C}$. (I) In vivo imaging of batch 2 and 3 lung tumor metastasis mouse by 116 MSOT (multispectral optoacoustic tomography). Anesthetized normal and tumor-induced mouse was 117 injected with TiNIR $(100 \mu \mathrm{M}, 100 \mu \mathrm{L} / 10 \mathrm{~g})$, and confirmed TiNIR signal in the lung region by MSOT 24 118 hour later. $(\mathrm{J})$ In vivo imaging of batch 1 lung tumor metastasis mouse model by MSOT. TiNIR signal 119 was compared with $\mathrm{Hb}$ or $\mathrm{HbO}_{2}$ signals. Those parameters were analyzed by MSOT software. (K) Other 120 batches of fluorescence ex vivo image of the control or tumor-induced lung. Mean fluorescence intensity 121 of ROI was calculated by Image J software. (L) Image of tumor-induced batch 2 mouse lung. (M) Image 122 of tumor-induced batch 3 lung and H\&E stained tissues. (N) Tumor image. After culture for 6 days of 123 each fraction (TiNIR ${ }^{\text {low }}$, and TiNIR ${ }^{\text {high }}$ ) isolated from tumor-induced lung lob cells, cells were injected to 124 both sides flank of mouse and 6 weeks later confirmed tumor generation. 
A

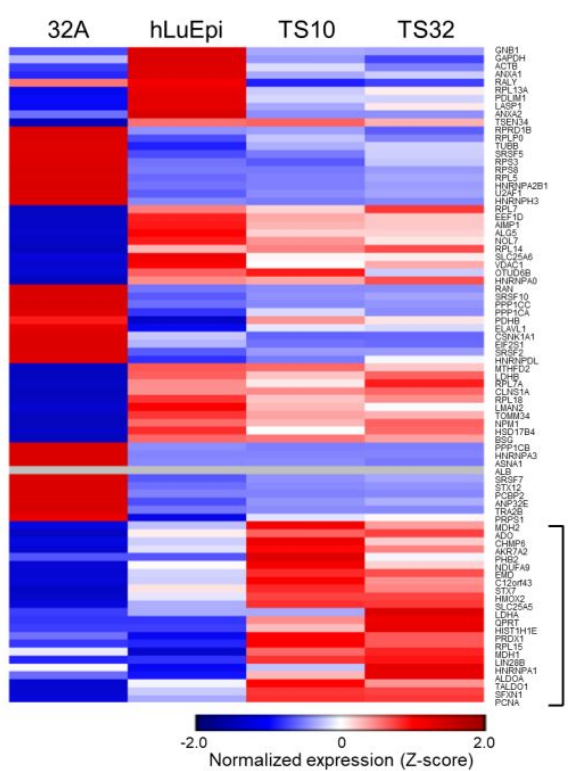

B
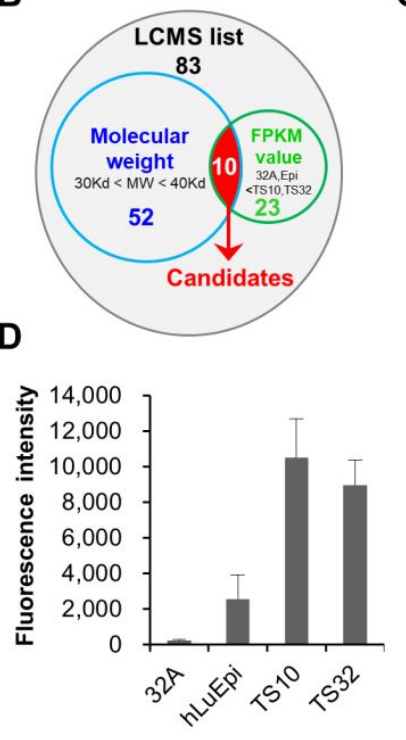

C

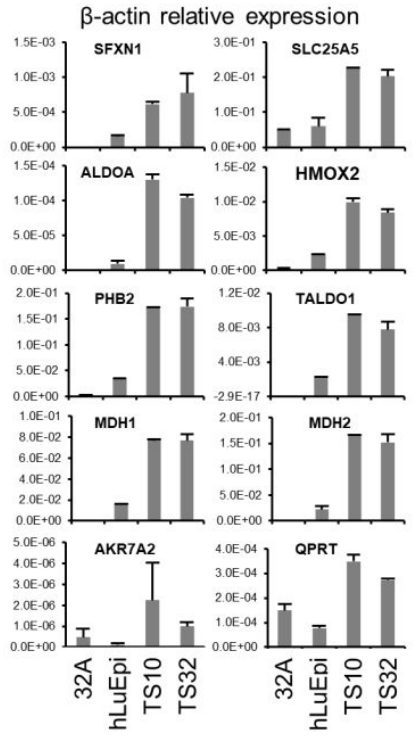

E

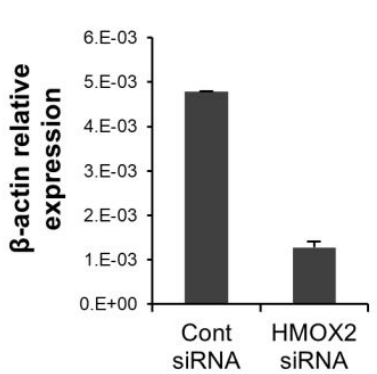

F
F

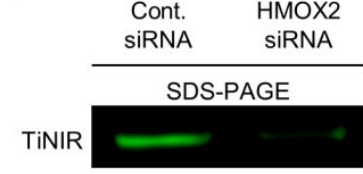

Western blot

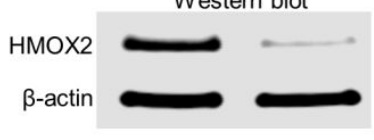

G

Wild HMOX2-KO

HMOX2

$\beta$-actin

H
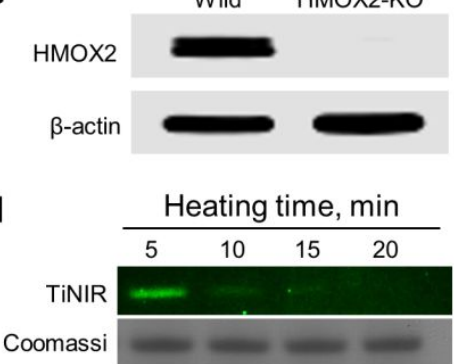

Heating time min
I

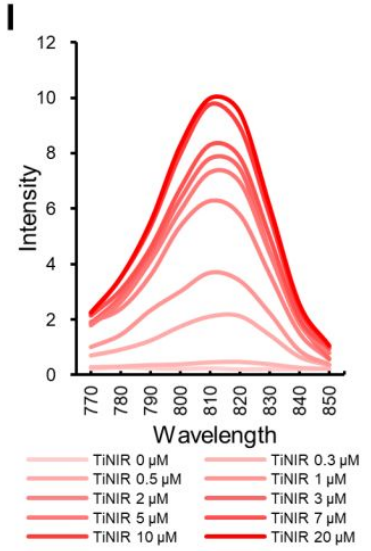

J

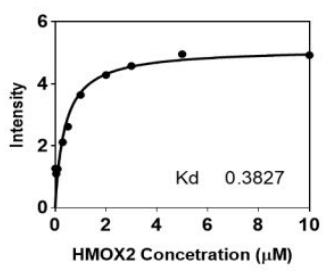

K

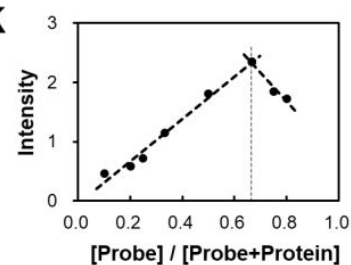

L

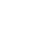

Figure S4. Scheme of target identification. (A) Heat map of the FPKM (Fragment Per Kilobase Million) value from NGS RNA-seq analysis. The list of heat map genes was obtained from LCMS result.

129 Indicated twenty genes showed the higher expression in the TiNIR positive (TS10 and TS32) cell lines

130 compared with TiNIR negative cells (32A and hLuEpi cells). (B) Venn diagram for narrow down of target.

131 Final 10 candidates selected through cross analysis between appropriate molecular weight list (52) and

132 FPKM value list (23) in the LCMS proteome list. (C) Quantification of target candidates mRNA 133 expression level in the TiNIR negative (32A and hLuEpi) and positive (TS10 and TS32) cells. Ten 134 candidates were chosen through analysis of the intersection between LCMS list (MW $>30 \mathrm{kDa}$ and $<40$ $135 \mathrm{kDa}$ ) and RNA-seq data (gene expression level: non-TIC<TIC). N=3. (D) TiNIR staining (10 nM, $40 \mathrm{~min})$ 
136 pattern in the four kinds of cell lines $\mathrm{N}=3$. (E) Knock-down of HMOX2 mRNA by treatment of siRNA.

137 This result was confirmed by qRT-PCR. $N=3$. (F) Correlation of gene knock-down and TiNIR staining 138 pattern. TS32 cells were treated with each indicated siRNAs (10 pmol) for 48 hours and stained by 139 TiNIR (10 nM, $\left.4{ }^{\circ} \mathrm{C}, 30 \mathrm{~min}\right)$. TiNIR signal was analyzed after extraction of protein and running of gel. 140 Protein expression was confirmed by western blot. (G) Image of HMOX2 expression in the wild-type 141 and HMOX2-KO cell lines. (H) Confirmation of TiNIR binding property with HMOX2 in different 142 denaturing time (from 0 to $20 \mathrm{~min}$ ). (I) Fluorescence spectra of TiNIR (from 0.3 to $20 \mu \mathrm{M}$ ) upon 143 incubation with HMOX2 $(10 \mu \mathrm{g})$ in 1\% DMSO PBS under excitation of $740 \mathrm{~nm}$ light. (J) Binding curve 144 of TiNIR and HMOX2. Various concentration of HMOX2 (from 0.01 to $10 \mu \mathrm{M}$ ) were incubated with TiNIR $145(1 \mu \mathrm{M})$ for $5 \mathrm{~min}$ in $1 \%$ DMSO PBS. Experimental $\mathrm{K}_{\mathrm{D}}=0.38 \mu \mathrm{M}$. (K) Job plot for florescence of the 146 probe (TiNIR)-protein (HMOX2) system at $810 \mathrm{~nm}$. [Probe + Protein] $=2 \mu \mathrm{M}$, excitation $=740 \mathrm{~nm}$. (L) 147 Structure of the other three hit compounds for TICs. (M) The binding property of three hit compounds 148 reaction with HMOX2. 
A

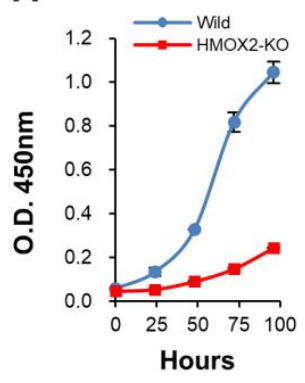

E

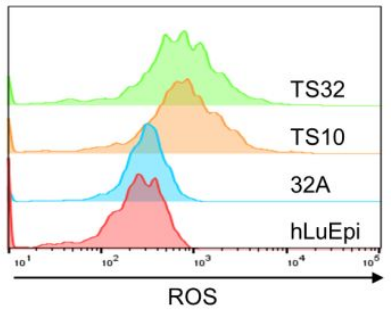

$\mathbf{F}$
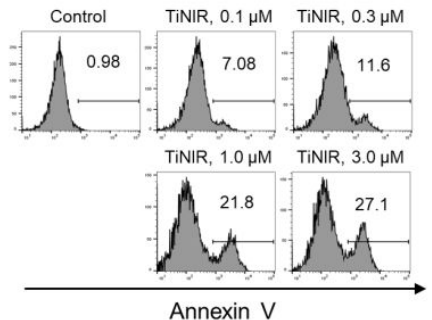

150
B

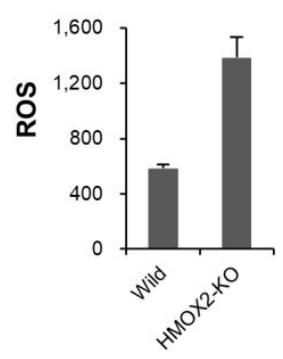

C

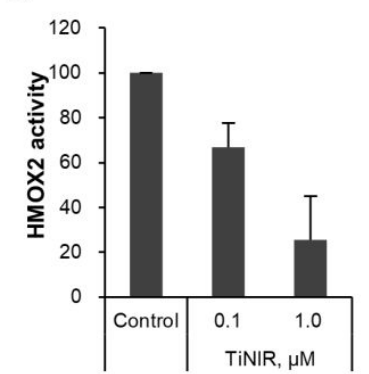

G

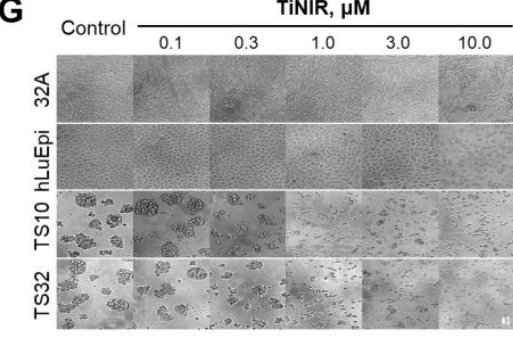

H

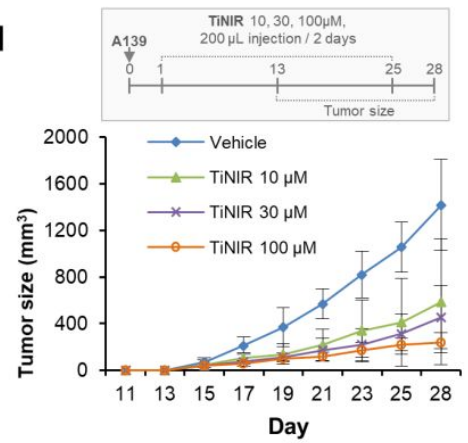

D

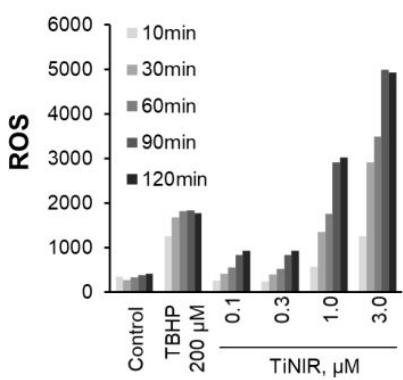

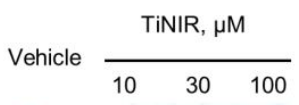

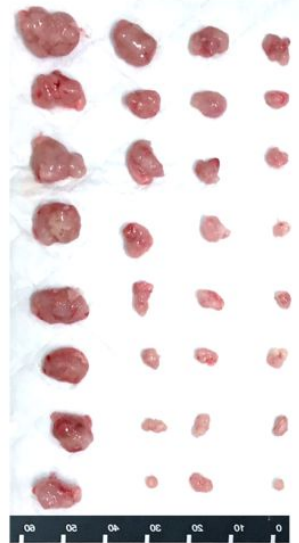

Figure S5. Therapeutic effect of TiNIR on the lung cancer. (A) Comparison of proliferation between wild-type and HMOX2-KO TS32 cells. After seeding of each cell $\left(1 \times 10^{4}\right.$ cells/well), proliferation was measured on indicated time point by CCK-8 kit. (B) Cellular ROS of wild-type and HMOX2-KO TS32 cells was measured by staining of DCFDA. To generate ROS, cells were given TBHP $(50 \mu \mathrm{M})$ for $30 \mathrm{~min}$, RT. N =3. (C) Inhibition the activity of the HMOX2 enzyme by TiNIR. Before reacting with hemin mixture, rhHMOX2 was incubated with TiNIR for $30 \mathrm{~min}, 37^{\circ} \mathrm{C}$. Relative hemin amount was measured in the $380 \mathrm{~nm}$ wavelength. (D) Cellular ROS analysis by DCFDA. TS32 cells were stained with DCFDA dye for $30 \mathrm{~min}$ and treated with TiNIR for $120 \mathrm{~min}$. Intracellular ROS generation was measured by flow cytometry. (E) Comparison of cellular ROS generation in the hLuEPi, 32A, TS10, and TS32 cells. cultured cells were stained by DCFDA dye for $30 \mathrm{~min}$ and treated with TiNIR for $60 \mathrm{~min}$. (F) Confirmation of apoptotic phenomenon by staining of annexin V. TS32 cells. Cells were treated with TiNIR for $30 \mathrm{~min}$ and 2 times washing by PBS before cultured. 24 hours later, cells were stained with Annexin V-FITC. (G) Microscopy image of TiNIR treated cells (hLuEpi, 32A, TS10, and TS32 cell). Cells were treated for $30 \mathrm{~min}$ as the indicated concentration of TiNIR and washed by PBS. Cells were counted after staining by trypan blue on 48 hours cultivation. $(\mathrm{H})$ Inhibition of tumor by TiNIR in tumor-bearing mice. From day 1 after post-injection of A139 PDX cells to subcutaneously, $100 \mu \mathrm{M}$ of TiNIR was injected into tail vein (200 $\mu \mathrm{L} /$ mouse) every couple of days until day 25 . Vehicle group was given the same volume of PBS. Tumors were sized until day 28. $\mathrm{N}=4$. (I) Tumor images. 
A
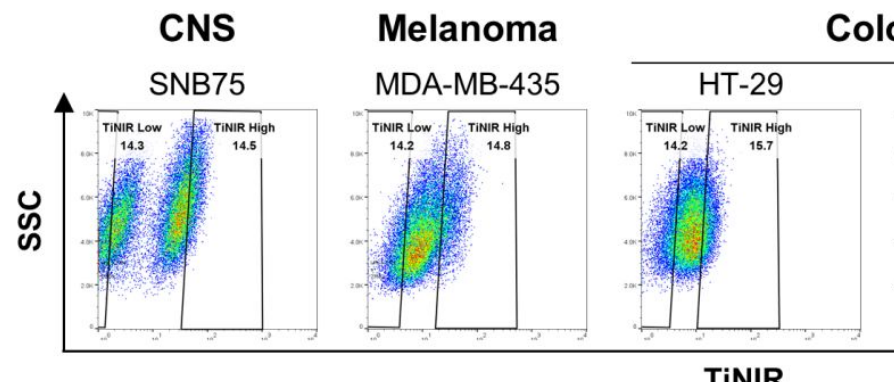

Colon

Prostate
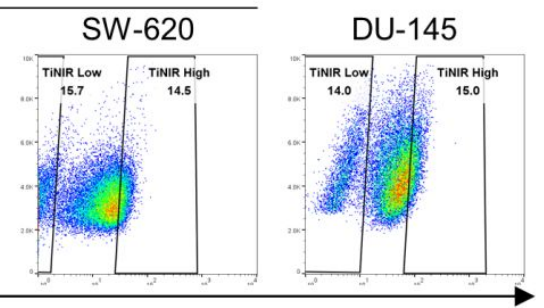

B
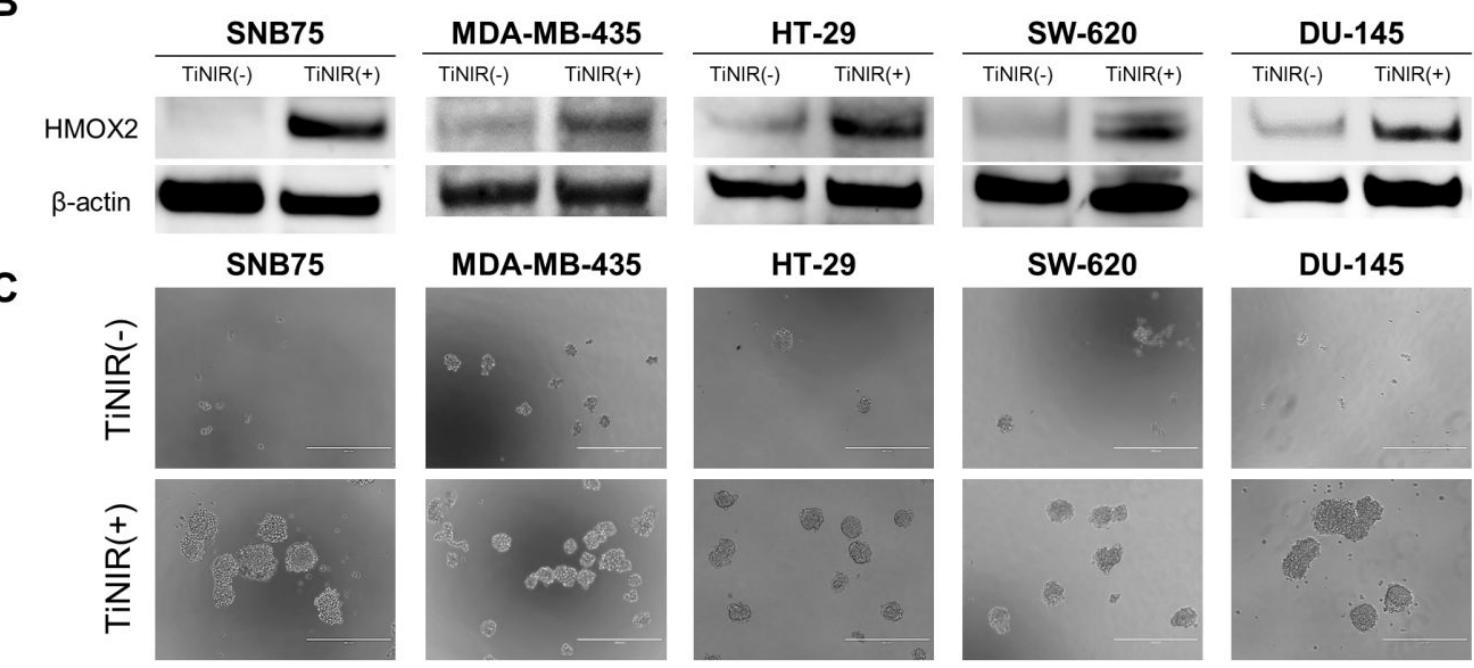

D
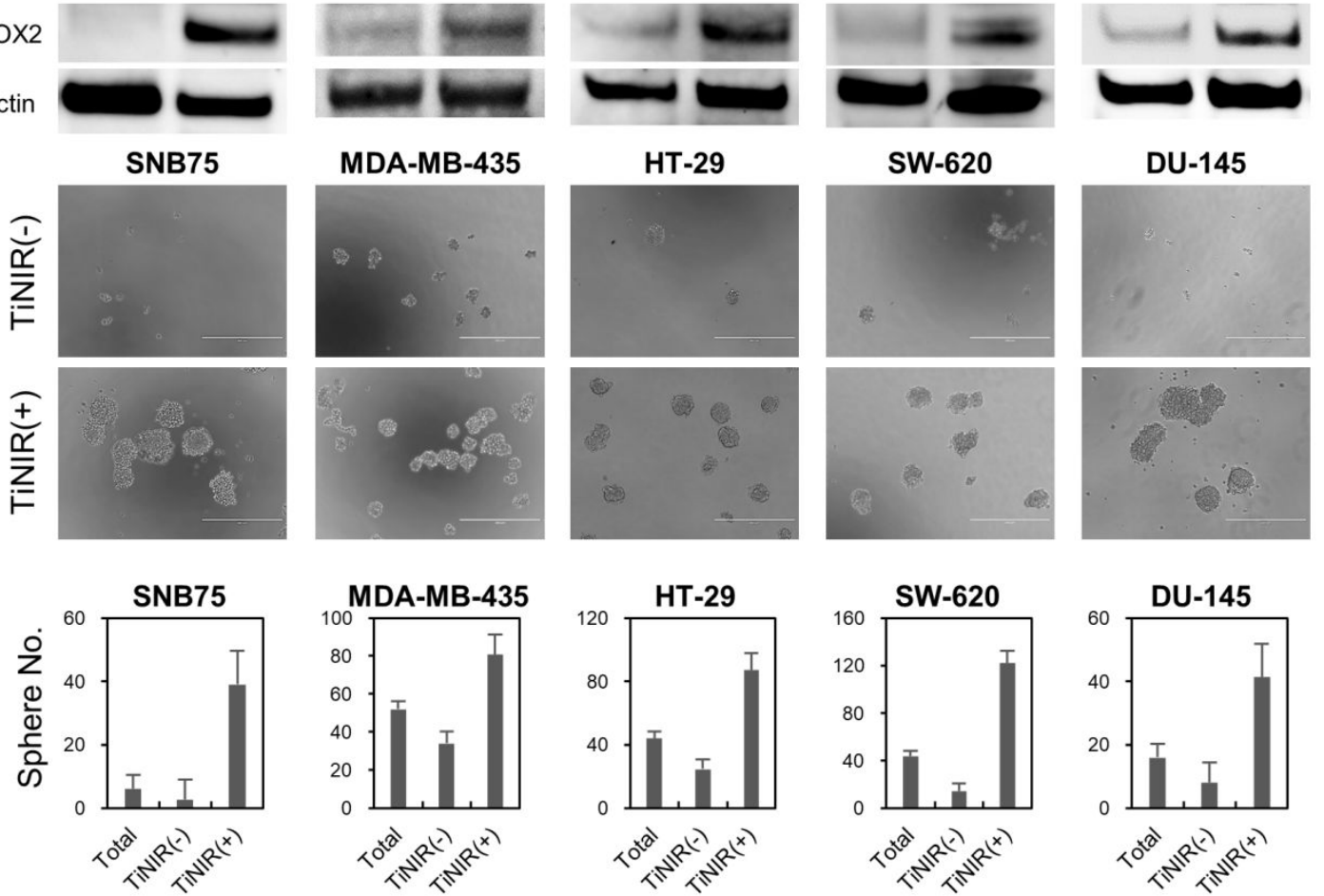

Figure S6. Assessment of the universality of TiNIR for TIC identification. After staining with TiNIR

171 (10nM), $15 \%$ of each population (TiNIR ${ }^{\text {low }}$, and TiNIR ${ }^{\text {high }}$ ) were sorted (200 cells/group) for evaluation

172 of the ability of tumor sphere forming. (A) Sorting strategy for low and high intensity population of the

173 various cancer cells lines after staining with the TiNIR (10 nM). (B) HMOX2 protein expression pattern

174 in the sorted TiNIR low and high fraction. Microscopy images (C) and sphere number (D) represent of 175 spheres on day $6-10$ from the seeding of each fraction. $N=3$. 


\section{Supporting Table.}

178 Table S1. The list of identified proteins from gel bands in the gel pieces by LCMS analysis.

\begin{tabular}{|c|c|c|}
\hline Description & Score & MW [kDa] \\
\hline Malate dehydrogenase, mitochondrial & 1547.5 & 35.5 \\
\hline L-lactate dehydrogenase $\mathrm{A}$ chain & 1427.8 & 36.7 \\
\hline Heterogeneous nuclear ribonucleoprotein A1 & 1188.7 & 38.7 \\
\hline Heterogeneous nuclear ribonucleoproteins A2/B1 & 1161.0 & 37.4 \\
\hline 60 S ribosomal protein L5 & 1065.9 & 34.3 \\
\hline Glyceraldehyde-3-phosphate dehydrogenase & 983.1 & 36.0 \\
\hline L-lactate dehydrogenase $B$ chain & 946.5 & 36.6 \\
\hline Annexin A2 & 648.6 & 38.6 \\
\hline Protein lin-28 homolog B & 438.1 & 27.1 \\
\hline 40 S ribosomal protein S3 & 427.4 & 26.7 \\
\hline Malate dehydrogenase, cytoplasmic & 379.8 & 36.4 \\
\hline Annexin A1 & 337.6 & 38.7 \\
\hline $60 \mathrm{~S}$ acidic ribosomal protein $\mathrm{P} 0$ & 317.8 & 34.3 \\
\hline Methylosome subunit pICln & 310.1 & 26.2 \\
\hline $60 S$ ribosomal protein $\mathrm{L} 7$ & 305.5 & 29.2 \\
\hline Heterogeneous nuclear ribonucleoprotein $\mathrm{A} 0$ & 283.4 & 30.8 \\
\hline Elongation factor 1-delta & 269.1 & 31.1 \\
\hline Transaldolase & 259.9 & 37.5 \\
\hline Aminoacyl tRNA synthase complex-interacting multifunctional protein 1 & 246.1 & 34.3 \\
\hline Heterogeneous nuclear ribonucleoprotein D-like & 236.2 & 46.4 \\
\hline Serine/arginine-rich splicing factor 2 & 223.5 & 25.5 \\
\hline Pyruvate dehydrogenase E1 component subunit beta, mitochondrial & 220.5 & 39.2 \\
\hline Serine/threonine-protein phosphatase PP1-alpha catalytic subunit & 218.9 & 37.5 \\
\hline Serine/threonine-protein phosphatase PP1-gamma catalytic subunit & 213.8 & 37.0 \\
\hline Prohibitin-2 & 192.3 & 33.3 \\
\hline Serine/threonine-protein phosphatase PP1-beta catalytic subunit & 191.5 & 37.2 \\
\hline Ribose-phosphate pyrophosphokinase 1 & 189.7 & 34.8 \\
\hline Peroxiredoxin-1 & 180.0 & 22.1 \\
\hline Bifunctional methylenetetrahydrofolate dehydrogenase/cyclohydrolase, mitochondrial & 170.5 & 37.9 \\
\hline Histone $\mathrm{H} 1.4$ & 169.0 & 21.9 \\
\hline Heterogeneous nuclear ribonucleoprotein A3 & 161.8 & 39.6 \\
\hline Splicing factor U2AF $35 \mathrm{kDa}$ subunit & 161.5 & 27.9 \\
\hline $40 \mathrm{~S}$ ribosomal protein S8 & 151.3 & 24.2 \\
\hline Nicotinate-nucleotide pyrophosphorylase [carboxylating] & 148.3 & 30.8 \\
\hline Heterogeneous nuclear ribonucleoprotein $\mathrm{H} 3$ & 148.1 & 36.9 \\
\hline Serine/arginine-rich splicing factor 7 & 144.3 & 27.4 \\
\hline Vesicular integral-membrane protein VIP36 & 139.5 & 40.2 \\
\hline Mitochondrial import receptor subunit TOM34 & 139.2 & 34.5 \\
\hline Nucleophosmin & 136.0 & 32.6 \\
\hline Heme oxygenase 2 & 131.9 & 36.0 \\
\hline Fructose-bisphosphate aldolase $\mathrm{A}$ & 131.1 & 39.4 \\
\hline GTP-binding nuclear protein Ran & 129.1 & 24.4 \\
\hline $60 \mathrm{~S}$ ribosomal protein $\mathrm{L} 15$ & 127.0 & 24.1 \\
\hline Serine/arginine-rich splicing factor 5 & 126.8 & 31.2 \\
\hline
\end{tabular}




\begin{tabular}{|c|c|c|}
\hline ADP/ATP translocase 2 & 125.8 & 32.8 \\
\hline Proliferating cell nuclear antigen & 123.0 & 28.8 \\
\hline Serum albumin & 121.2 & 69.3 \\
\hline OTU domain-containing protein $6 \mathrm{~B}$ & 115.2 & 33.8 \\
\hline Peroxisomal multifunctional enzyme type 2 & 111.0 & 79.6 \\
\hline $60 S$ ribosomal protein $L 18$ & 105.6 & 21.6 \\
\hline LIM and $\mathrm{SH} 3$ domain protein 1 & 105.3 & 29.7 \\
\hline Aflatoxin B1 aldehyde reductase member 2 & 104.83 & 39.6 \\
\hline Charged multivesicular body protein 6 & 104.4 & 23.5 \\
\hline $60 S$ ribosomal protein $\mathrm{L} 7 \mathrm{a}$ & 102.9 & 30.0 \\
\hline Sideroflexin-1 & 102.9 & 35.6 \\
\hline ATPase ASNA1 & 101.3 & 38.8 \\
\hline PDZ and LIM domain protein 1 & 100.5 & 36.0 \\
\hline tRNA-splicing endonuclease subunit Sen34 & 99.9 & 33.6 \\
\hline Syntaxin-12 & 99.6 & 31.6 \\
\hline Poly(rC)-binding protein 2 & 98.8 & 38.6 \\
\hline Acidic leucine-rich nuclear phosphoprotein 32 family member $E$ & 98.3 & 30.7 \\
\hline Transformer-2 protein homolog beta & 97.5 & 33.6 \\
\hline $60 S$ ribosomal protein $\mathrm{L} 13 \mathrm{a}$ & 97.2 & 23.6 \\
\hline Voltage-dependent anion-selective channel protein 1 & 96.2 & 30.8 \\
\hline Serine/arginine-rich splicing factor 10 & 95.9 & 31.3 \\
\hline 2-aminoethanethiol dioxygenase & 95.8 & 29.7 \\
\hline ADP/ATP translocase 3 & 93.0 & 32.8 \\
\hline Basigin OS=Homo sapiens & 88.9 & 42.2 \\
\hline ELAV-like protein 1 & 86.2 & 36.1 \\
\hline Casein kinase I isoform alpha OS=Homo sapiens & 86.0 & 38.9 \\
\hline Eukaryotic translation initiation factor 2 subunit 1 & 84.1 & 36.1 \\
\hline 60 S ribosomal protein $\mathrm{L} 14$ & 83.4 & 23.4 \\
\hline Dolichyl-phosphate beta-glucosyltransferase & 82.8 & 36.9 \\
\hline Regulation of nuclear pre-mRNA domain-containing protein 1B & 81.5 & 36.9 \\
\hline RNA-binding protein Raly & 81.1 & 32.4 \\
\hline Tubulin beta chain & 77.2 & 49.6 \\
\hline Emerin & 77.0 & 29.0 \\
\hline Actin, cytoplasmic 1 & 76.1 & 41.7 \\
\hline Syntaxin-7 OS=Homo sapiens & 75.3 & 29.8 \\
\hline Guanine nucleotide-binding protein $\mathrm{G}(\mathrm{I}) / \mathrm{G}(\mathrm{S}) / \mathrm{G}(\mathrm{T})$ subunit beta-1 & 74.8 & 37.4 \\
\hline Nucleolar protein & 73.9 & 29.4 \\
\hline NADH dehydrogenase [ubiquinone] 1 alpha subcomplex subunit 9 , mitochondrial & 71.5 & 42.5 \\
\hline Uncharacterized protein C12orf43 & 71.3 & 28.2 \\
\hline
\end{tabular}

179 The proteins highlighted by gray background in the table indicate the protein molecular weight is $180>30 \mathrm{kD}$ and $<40 \mathrm{kd}$. 